\title{
Evaluation of Air Quality in Volta Redonda, the Main Metallurgical Industrial City in Brazil
}

\author{
Adriana Gioda ${ }^{*, a, b}$, José A. Sales ${ }^{c}$, Paulina M. S. Cavalcanti ${ }^{c}$, Marilza F. Maia ${ }^{c}$, Luiz F. P. G. Maia $^{d}$ \\ and Francisco R. Aquino Neto ${ }^{a}$
}

${ }^{a}$ Instituto de Química, Centro de Tecnologia, Bloco A, Sala 607, Ilha do Fundão, Universidade Federal do Rio de Janeiro, 21949-900 Rio de Janeiro-RJ, Brazil

${ }^{b}$ Departamento de Química, Universidade da Região de Joinville, Campus Universitário s/n, Bom Retiro, 89201-972 Joinville-SC, Brazil

${ }^{c}$ DIAAR/FEEMA-Governo do Estado do Rio de Janeiro, Av. Nossa Senhora de Copacabana 493, $6^{\circ}$ andar, 22020-000 Rio de Janeiro - RJ, Brazil

${ }^{d}$ Departamento de Meteorologia, IGEO-CCMN, Ilha do Fundão, Universidade Federal do Rio de Janeiro, 21949-900 Rio de Janeiro-RJ, Brazil

\begin{abstract}
A maior indústria de aço do Brasil está situada na cidade de Volta Redonda, RJ. A produção de coque neste tipo de indústria é a maior fonte de emissão de compostos aromáticos. Com objetivo de implementar medidas de controle da poluição nas indústrias a FEEMA, agência ambiental do Estado do Rio de Janeiro, avaliou a qualidade do ar naquela cidade em Dec/95-Mai/96 e Abr-Mai/99. Na primeira campanha, material particulado total (MPT), benzeno, tolueno, xilenos (BTX) e dióxido de enxofre $\left(\mathrm{SO}_{2}\right)$ foram analisados e concentrações médias altas foram encontradas: $102 \mu \mathrm{g} \mathrm{m}^{-3}$, $70 \mu \mathrm{g} \mathrm{m}^{-3}, 23 \mu \mathrm{g} \mathrm{m}^{-3}, 2,5 \mu \mathrm{g} \mathrm{m}^{-3} \mathrm{e} 186 \mu \mathrm{g} \mathrm{m}^{-3}$, respectivamente. Após medidas drásticas de controle, a segunda avaliação (Abr-Mai/99), apresentou valores menores: $102 \mu \mathrm{g} \mathrm{m}^{-3}$ (TSP); $62 \mu \mathrm{g} \mathrm{m}^{-3}$ $\left(\mathrm{PM}_{10}\right), 23 \mu \mathrm{g} \mathrm{m}^{-3}(\mathrm{~B}), 4 \mu \mathrm{g} \mathrm{m}^{-3}(\mathrm{~T}), 0,6 \mu \mathrm{g} \mathrm{m}^{-3}(\mathrm{X}), 73 \mu \mathrm{g} \mathrm{m}^{-3}\left(\mathrm{SO}_{2}\right)$ além de metais. Esses resultados, principalmente para benzeno, indicam que o programa de monitoramento deve continuar até atingir a solução final para o problema.
\end{abstract}

The largest steel plant in Brazil is located in Volta Redonda city, RJ. Coke production in this kind of industry is the major emission source of aromatic compounds. Aiming the implementation of pollution control measures in industries, FEEMA, Rio de Janeiro State environmental agency, evaluated air quality in that city in Dec/95-May/96 and Apr-May/99. In the first campaign, total suspended particles (TSP), benzene, toluene, xylenes (BTX) and sulfur dioxide $\left(\mathrm{SO}_{2}\right)$ were analyzed and high average concentrations were found $102 \mu \mathrm{g} \mathrm{m}^{-3}, 70 \mu \mathrm{g} \mathrm{m}^{-3}, 23 \mu \mathrm{g} \mathrm{m}^{-3}, 2.5 \mu \mathrm{g} \mathrm{m}^{-3}$ and $186 \mu \mathrm{g} \mathrm{m}^{-3}$, respectively. Following drastic control measures, the second evaluation (Apr-May/99) showed values that dropped to $102 \mu \mathrm{g} \mathrm{m}^{-3}$ (TSP); $62 \mu \mathrm{g} \mathrm{m}^{-3}\left(\mathrm{PM}_{10}\right), 23 \mu \mathrm{g} \mathrm{m}^{-3}$ (B), $4 \mu \mathrm{g} \mathrm{m}^{-3}$ (T), $0.6 \mu \mathrm{g} \mathrm{m}^{-3}(\mathrm{X}), 73 \mu \mathrm{g} \mathrm{m}^{-3}\left(\mathrm{SO}_{2}\right)$ besides metals. These results, mainly for benzene, indicate that the monitoring program must continue until a final solution for this problem is reached.

Keywords: air pollution, BTX, particulate matter, steel industry, outdoor air

\section{Introduction}

Volta Redonda, a city in Rio de Janeiro State, grew around the largest steel producing plant in Brazil. It has a current population of 250,000 inhabitants, and is the source of one of the state's main revenues. ${ }^{1}$ Its environmental problems are basically related to air pollution resulting from the type and location of the

* e-mail: gioda@iq.ufrj.br region's industrial activities. The most important source of organic pollutants in the monitored area is coke production at National Steel Company (CSN) (4.6 x $10^{6}$ metric tons/year). Volta Redonda is located in a strategic area - halfway between São Paulo and Rio de Janeiro (BR 393 road). Thus, there is high air pollution potential due to vehicles motor exhaust from heavy traffic. Furthermore, many other metallurgical and cement factories were established there to supply CSN demand, contributing to the complex array of possible air pollution sources. 
Depending on the type of industry, particles, sulfur dioxide and organic compounds constitute the main atmospheric pollutants. ${ }^{1}$ The concentration, composition and particle size of suspended particulate matter are determined by such factors as meteorological properties of the atmosphere, topographical influences, emission sources, and particle parameters such as density, shape, and hygroscopicity. ${ }^{2}$ Particulate matter less or equal to $10 \mu \mathrm{m}$ in diameter is associated with adverse health effects including increased respiratory problems, mortality and increase of cancer in some urban areas. ${ }^{3}$ By the same token, the chemical composition of particles (Polycyclic Aromatic Hydrocarbons (PAHs), metals, acidity) can induce health-related effects. ${ }^{2}$ Benzene, toluene and xylenes (BTX) are present in the environment because of emissions from automobiles, petrochemical industry and combustion processes. Due to the toxicity and mutagenic or carcinogenic properties of $\mathrm{BTX},{ }^{4}$ aromatic hydrocarbon air pollution is a very important topic for environmental health. Although significant, few are the studies related to atmospheric pollution in Brazil. These researches, most related to the effects of traffic, have been basically carried out in large metropolis such as São Paulo, ${ }^{5,6}$ Rio de Janeiro, ${ }^{7-11}$ Porto Alegre, ${ }^{12,13}$ Salvador $^{14}$ and in the Amazonian region. ${ }^{15}$ There are few studies concerning industrial areas.

Aiming to follow the implementation of pollution control measures in industries, FEEMA, the Rio de Janeiro State environmental agency, in partnership with Laboratório de Apoio ao Desenvolvimento Tecnológico (LADETEC/ UFRJ) and Department of Meteorology of Universidade Federal do Rio de Janeiro (IGEO/UFRJ) evaluated air quality in several sampling sites in Volta Redonda. Two evaluations were performed in Dec/95-May/96 and Apr-May/99. The parameters were chosen according to national and international recommendations. The objective of this study was to obtain information regarding air quality in the Municipal District of Volta Redonda, so as to permit the proposal of new pollution control policies, and to increase the population awareness about eventual high pollution levels and environmental degradation. The results can be used in the evaluation of the existing monitoring program and may contribute to the generation of new pollution control strategies to evaluate and restructure the existent network of antipollution devices/procedures.

\section{Experimental}

\section{Monitored area}

The Municipal District of Volta Redonda is located on the margins of the Paraíba do Sul river, between the Mantiqueira and Mar mountain ranges, parallels 22 22' 11" and $2238^{\prime}$ of South latitude, and the meridians $44^{\circ} 09^{\prime} 25^{\prime \prime}$ and $44^{\circ} 20^{\prime}$ of West longitude. Its urban perimeter occupies an area of $54 \mathrm{~km}^{2}$ corresponding to $0.4 \%$ of the total area of the state of Rio de Janeiro. Its altitude varies widely, from 363 $\mathrm{m}$ at Paraibas's river margins to $707 \mathrm{~m}$ (in the northeast tip) above the sea level, while the altitude at the central area is $380.3 \mathrm{~m}$. According to a study published by FEEMA, ${ }^{16}$ the climate of Volta Redonda can be classified as mesotermic with a compensated medium temperature of $21^{\circ} \mathrm{C}$. The annual maximum average is $27.8^{\circ} \mathrm{C}$ and the monthly minimum average is $16.5^{\circ} \mathrm{C}$. The rainy season runs from October to March, including summer, and it averages 130 days of rain/ year. January and February are the months of larger pluviometric index. The mean relative air humidity is $77 \%$, with August and September as the least humid months.

The monitoring was performed in five stations located at strategic places within the Municipal District perimeter. The choice of the sampling points in the monitoring evaluation was based on: first, the representativeness of areas with high population density or intense traffic; second, areas surrounding main pollution sources with the correct predominant wind direction. Using these criteria, four sampling points were selected, leeward (downwind) of the emission sources, while a point to windward (upwind) was chosen as a reference station. They were FEEMA (FE), Belmonte (BE), Retiro (RE), and Centro de Pesquisas stations (CP) to leeward and Aeroclube (AE) to windward (background). These stations are located in Figure $1 .{ }^{1}$ The urban area of Volta Redonda is dominated mainly by metallurgic industries such as CSN (National Steel Company), FEM (Plant of Metallic Structures), CESBRA (Tin Company of Brazil), Voldac Casting, and cement

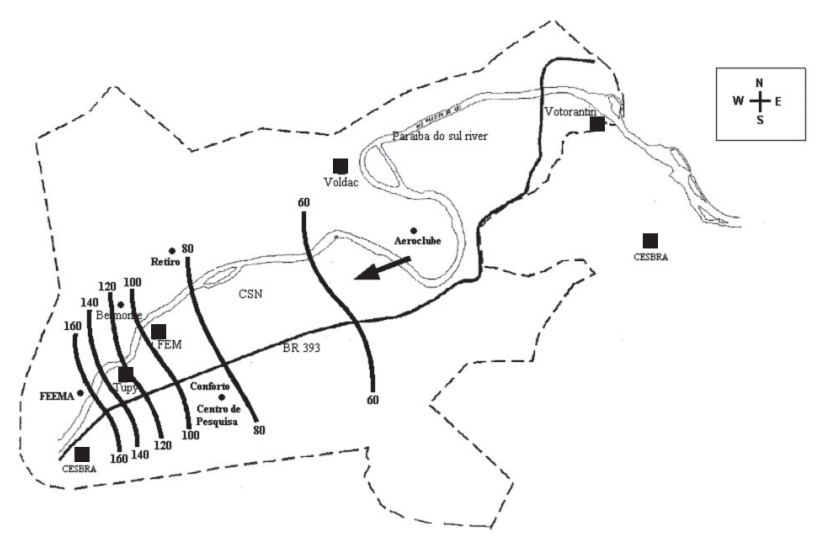

Figure 1. TSP average spatial distribution in Volta Redonda in the first evaluation (Dez/95-May/96). Sampling locations: (O) FEEMA, Belmonte, Aeroclube and Centro de Pesquisas. Main siderurgical activities: (ם) CSN (National Steel Company), FEM (Plant of Metallic Structures), CESBRA (Tin Company of Brazil), Voldac Casting, Tupy Cement and Votorantin Cement. (---) Municipal boundary. (-) BR 393 road. Isolines concentration $\left(\mu \mathrm{g} \mathrm{m}^{-3}\right)$. 
industries like Tupy Cement and Votorantin Cement. These may also be considered as considerable emitting sources. ${ }^{1}$

In the first evaluation (Dec/95-May/96), Belmonte, Retiro, Centro de Pesquisass and Aeroclube were equipped to measure the concentrations of total suspended particles (TSP) and Benzene, Toluene and Xylenes (BTX). FEEMA was able to measure TSP, BTX, sulphur dioxide $\left(\mathrm{SO}_{2}\right)$, wind speed and direction. In the second evaluation (Apr-May/ 99), TSP and metals in TPS (FEEMA, Belmonte, Retiro, Aeroclube and Conforto), inhalable particles $\left(\mathrm{PM}_{10}\right)$ and metals in PM $_{10}$ (FEEMA, Belmonte and Conforto), BTX (FEEMA and Retiro) and $\mathrm{SO}_{2}$ (FEEMA) were collected and analyzed. Conforto substituted Centro de Pesquisas station.

\section{Total suspended particles (TSP) and inhalable particles $\left(P M_{10}\right)$}

TSP was collected using a high-volume air sampler, HiVol (Andersen, Smyrna, GA, USA) fitted with fiberglass filter of $8 \times 10$ inches, having an air flow of 1.1 to $1.7 \mathrm{~m}^{3} \mathrm{~min}^{-1}$ for a continuous $24 \mathrm{~h}$ period. Particulate matter (PM), with a diameter up to $100 \mu \mathrm{m}$ was retained in the filter. To analyze $\mathrm{PM}_{10}$ a Hi-Vol sampler impactor capable of retaining particles $\leq 10 \mu \mathrm{m}$ was used. TSP and $\mathrm{PM}_{10}$ concentrations were gravimetrically determined. In the particulate matter, metals concentrations were determined in the second sampling. In the first evaluation (Dec/95-May/96), TSP sampling was effected each $24 \mathrm{~h}, 45$ samples being collected. In the second evaluation (Apr-May/99), it was carried out every two days, corresponding to 10 samples.

\section{Metals}

The particles retained in the fiber glass filter ( $\mathrm{Hi}-\mathrm{Vol})$ were submitted ( $1 / 6$ of the filter) to a nitric acid $3 \mathrm{~mol} \mathrm{~L}^{-1}$ (Merck, Darmstadt, Germany) hot digestion. Metals dissolved in the sample were determined by Flame Atomic Absorption Spectrophotometry CG 904 model using hollow cathode lamp to each metal to be analyzed: Cadmium (Cd), Chromium (Cr), Copper ( $\mathrm{Cu})$, Iron $(\mathrm{Fe})$, Lead ( $\mathrm{Pb})$, Manganese (Mn), Nickel (Ni), Vanadium (V) and Zinc $(\mathrm{Zn}) .{ }^{17}$ Blank filters and reagents were analyzed for each sampling for the determinations of possible contamination. The average metal content of the blanks represent less than $5 \%$ of the samples average metal content. Detection limit was $0.04 \mu \mathrm{g} \mathrm{m}^{-3}$. Metals were sampled in a total of 11 days.

\section{Benzene, toluene and xylenes (BTX)}

Air was pumped (1 to $2 \mathrm{~L} \mathrm{~min}^{-1}$ ) through adsorbent tubes (Supelco ORBO 100, batch 6719, Bellefonte, PA, EUA), which contained two sections of activated charcoal. Mean volume of pumped air was $1.5 \mathrm{~m}^{3} 24 \mathrm{~h}^{-1}$. Solvent desorption with carbon disulfide (Tedia, Fairifield, $\mathrm{OH}$, USA) was used. $2 \mu \mathrm{L}$ of samples were injected into a 25 meter capillary column (CARBOWAX 20 M - HP-20M; $25 \mathrm{~m} \times 0.2 \mathrm{~mm}$, film thickness $0.2 \mu \mathrm{m}$ ) attached to a Hewlett-Packard 5890 GC, Series II with flame ionization detector (FID). Split mode 1:100 was used. Temperature of the injector and detector were $250{ }^{\circ} \mathrm{C}$. The temperature of the column oven was maintained initially at $30{ }^{\circ} \mathrm{C}$ for 12 min, then increased at $25^{\circ} \mathrm{C}$ per minute to $180{ }^{\circ} \mathrm{C}$. BTX standard solutions were prepared from high purity standards obtained commercially (Riedel, Phillips and Ecibra). Dilutions were made with $\mathrm{CS}_{2}$ to build a calibration curve with 5 different standard concentrations $\left(13,26,52,104,208 \mathrm{mg} \mathrm{L}^{-1}\right)$. The samples were injected in duplicate and blanks and standard solutions in triplicate. Blank values were around $5 \mathrm{mg} \mathrm{\textrm {L } ^ { - 1 }}$. Standard deviations between sample injections were less than $10 \%$. Dectection limit of method was $1 \mu \mathrm{g} \mathrm{m}^{-3}$. BTX sampling, in the first evaluation (Dec/95-May/96), was realized continuously, during seven days every month, corresponding to 42 sampling days. In the second one, it was collected every two days, in a total of 11 days. In both evaluations, two samples were collected during 12 hours.

\section{Sulphur dioxide $\left(\mathrm{SO}_{2}\right)$}

During the campaign an automatic analyzer (Thermo Electron Corporation, Houston, TX, USA) was used continuously to measure the concentrations of sulphur dioxide. The employed methodology was based on fluorescence UV. The measurement of sulphur dioxide was registered every 10,15 or $20 \mathrm{~min}$ and averaged for each hour. $\mathrm{SO}_{2}$ was sampled for 122 days in the first evaluation (Dec/95-May/96) and 16 days in the second one (AprMay/99). Calibration is made each $24 \mathrm{~h}$ and annually by the manufacturer.

\section{Meteorological data}

In this first diagnostic phase, the daily synoptic charts of the schedule South America of 12:00 UTC (Universal Cardinale Teams) were used. They corresponded to the 9:00 hours local (in regular civil schedule), were elaborated and divulged by the Brazilian Navy Directorate of Hydrography and Navigation in agreement with information obtained from 4 meteorological stations from the Brazilian National Meteorological Institute (INMET), and the data from the National Center of Environmental 
Prediction (NCEP) of the United States. In the second monitoring evaluation, the results generated by the meteorological station at $\mathrm{CSN}$ were used. The wind regime came from the East, and varied from Northeast to Southeast. ${ }^{1}$

\section{Results and Discussion}

In Brazil, the threshold limit for the majority of compounds in outdoor air is set by Conselho Nacional do Meio Ambiente (CONAMA) ${ }^{18}$ However, some pollutants still do not have any established air quality standards. In these cases, international standards (European Environmental Agency-EEA, ${ }^{19}$ U.S. Environmental Protection Agency-USEPA ${ }^{20}$ and World Health Organization - $\mathrm{WHO}^{21}$ ) were adopted as reference. Due to the fact that the sampling period in both campaigns was less than one year, the results will be compared with $24 \mathrm{~h}$ standards suggested by the agencies; if not available the annual standard will be used.

\section{Total suspended particles (TSP)}

Table 1 presents averages, as well as minimum and maximum values of total suspended particles obtained during both evaluations in Volta Redonda and guideline values. All sampling sites in both evaluations did not exceed the daily limit for TSP according to $\operatorname{CONAMA}^{18}\left(240 \mu \mathrm{g} \mathrm{m}^{-3}\right)$ or $\operatorname{EEA}^{19}\left(250 \mu \mathrm{g} \mathrm{m}^{-3}\right)$. But, FEEMA station presented maximum concentration higher than the primary $24 \mathrm{~h}$ standard established by these agencies in both cases.
FEEMA and Belmonte stations presented the highest concentration averages, while Aeroclube presented the lowest in both evaluations. TSP average spatial distribution shows a clear increase from Northeast to Southwest (Figure 1). The isolines in Figure 1 refer to distribution of TSP concentrations in Volta Redonda according to wind direction. It can be stated that the gradient of TSP concentration is lower windward to CSN than leeward. The handling of iron ores and the burning of coal at CSN plant can origin the plume of pollution that reach FEEMA and Belmonte stations (leeward) but not reach Aeroclube (windward to CSN). Votorantin cement, which emits particulate matter in its process, seems not to influence TSP levels in Aeroclube station. Perhaps, the distance between station and plant is big enough to disperse or settle the particles. Low levels of TSP in this station were observed in both campaigns. But, Tupy cement can have some influence in PM mainly in FEEMA station due to their proximity. The highest levels (average and maximum) of TSP detected in both campaigns suggested this influence.

The average concentrations found for TSP in Volta Redonda (54-163 $\left.\mu \mathrm{g} \mathrm{m}^{-3}\right)$ are lower than the average concentration found in polluted areas in Rio de Janeiro (68-198 $\left.\mu \mathrm{g} \mathrm{m}^{-3}\right)$ according to FEEMA. ${ }^{1}$ In another research, Azevedo et al. ${ }^{9}$ found 27 to $348 \mu \mathrm{g} \mathrm{m}^{-3}$ TSP in industrial and heavy traffic areas in Rio de Janeiro. Dos Santos et al. ${ }^{11}$ measured concentrations within $110-399 \mu \mathrm{g} \mathrm{m}^{-3}$ of TSP near the crop burning region in Campos dos Goytacazes, RJ, Brazil. In other cities (Table 2) average concentrations were $56-113 \mu \mathrm{g} \mathrm{m}^{-3}$, i. e., lower than Volta Redonda.

Table 1. Average (range in parenthesis) concentrations of TSP, $\mathrm{PM}_{10}$, BTX and $\mathrm{SO}_{2}$ during sampling period (Dec/95-May/96 and Apr-May/99) in Volta Redonda city and guideline limits for these compounds suggested by national and international agencies

\begin{tabular}{|c|c|c|c|c|c|c|c|c|c|c|c|}
\hline \multirow[t]{3}{*}{ Station } & \multicolumn{2}{|c|}{$\operatorname{TSP}\left(\mu \mathrm{g} \mathrm{m}^{-3}\right)$} & \multirow{3}{*}{$\begin{array}{l}\mathrm{PM}_{10}\left(\mu \mathrm{g} \mathrm{m}^{-3}\right) \\
1999 \\
\mathrm{n}=10\end{array}$} & \multicolumn{2}{|c|}{$\operatorname{Benzene}\left(\mu \mathrm{g} \mathrm{m}^{-3}\right)$} & \multicolumn{2}{|c|}{ Toluene $\left(\mu \mathrm{g} \mathrm{m}^{-3}\right)$} & \multicolumn{2}{|c|}{ Xylenes $\left(\mu \mathrm{g} \mathrm{m}^{-3}\right)$} & \multicolumn{2}{|c|}{$\mathrm{SO}_{2}\left(\mu \mathrm{g} \mathrm{m}^{-3}\right)$} \\
\hline & $1995-96$ & 1999 & & $1995-96$ & 1999 & $1995-96$ & 1999 & $1995-96$ & 1999 & $1995-96$ & 1999 \\
\hline & $\mathrm{N}=45$ & $\mathrm{n}=11$ & & $\mathrm{n}=42$ & $\mathrm{n}=11$ & $\mathrm{n}=42$ & $\mathrm{n}=11$ & $\mathrm{n}=42$ & $\mathrm{n}=11$ & $\mathrm{n}=122$ & $\mathrm{n}=16$ \\
\hline FEEMA & $163(76-286)$ & $154(76-445)$ & $78(27-125)$ & $83(3-705)$ & $20(11-104)$ & $21(1-121)$ & 4.4(nd-14) & 3(nd-13) & $1.1($ nd- 7.5$)$ & $186(52-354)$ & $73(6-131)$ \\
\hline Belmonte & $116(48-198)$ & $110(75-136)$ & $65(41-83)$ & $52(3-340)$ & $*$ & 30(nd-156) & $*$ & $1.7(1-35)$ & $*$ & $*$ & $*$ \\
\hline Retiro & $95(41-171)$ & $90(70-107)$ & $*$ & 93(nd-1644) & 26(nd-90) & 25(nd-382) & $3.7($ nd-7) & $2.7($ nd-28) & nd & $*$ & $*$ \\
\hline Aeroclube & $54(20-127)$ & $68(46-96)$ & $*$ & 58(nd-430) & $*$ & 20(nd-208) & $*$ & $2.3($ nd-29) & $*$ & $*$ & $*$ \\
\hline Centro & $82(36-161)$ & $87(63-114)$ & $44(20-64)$ & 65(nd-1451) & $*$ & 17(nd-355) & $*$ & 3(nd-42) & $*$ & $*$ & $*$ \\
\hline \multicolumn{12}{|l|}{ Pesquisas/ } \\
\hline \multicolumn{12}{|l|}{ Conforto } \\
\hline CONAMA $^{18}$ & \multirow{2}{*}{\multicolumn{2}{|c|}{$240 \mu \mathrm{g} \mathrm{m}^{-3} 24 \mathrm{~h}$ average }} & $150 \mu \mathrm{g} \mathrm{m}^{-3}$ & \multirow{2}{*}{\multicolumn{2}{|c|}{ - }} & \multirow{2}{*}{\multicolumn{2}{|c|}{-}} & \multirow{2}{*}{\multicolumn{2}{|c|}{-}} & \multirow{2}{*}{\multicolumn{2}{|c|}{$365 \mu \mathrm{g} \mathrm{m}^{-3} 24 \mathrm{~h}$ average }} \\
\hline Standards & & & $24 \mathrm{~h}$-average & & & & & & & & \\
\hline EEA $^{19}$ & \multirow{2}{*}{\multicolumn{2}{|c|}{$250 \mu \mathrm{g} \mathrm{m}^{-3} 24 \mathrm{~h}$-average }} & - & \multirow{2}{*}{\multicolumn{2}{|c|}{-}} & \multicolumn{2}{|c|}{$260 \mu \mathrm{g} \mathrm{m}^{-3} 1$ week } & \multirow{2}{*}{\multicolumn{2}{|c|}{$4.8 \mathrm{mg} \mathrm{m}^{-3} 24 \mathrm{~h}$ average }} & \multicolumn{2}{|c|}{$300 \mu \mathrm{g} \mathrm{m}^{-3} 24 \mathrm{~h}$ average } \\
\hline \multicolumn{7}{|l|}{ Standards } & & & & & \\
\hline USEPA $^{20}$ & \multirow{2}{*}{\multicolumn{2}{|c|}{-}} & $150 \mu \mathrm{g} \mathrm{m}^{-3}$ & \multirow{2}{*}{\multicolumn{2}{|c|}{-}} & \multirow{2}{*}{\multicolumn{2}{|c|}{-}} & \multirow{2}{*}{\multicolumn{2}{|c|}{-}} & \multirow{2}{*}{\multicolumn{2}{|c|}{$365 \mu \mathrm{g} \mathrm{m}^{-3} 24 \mathrm{~h}$-average }} \\
\hline Standards & & & $24 \mathrm{~h}$ average & & & & & & & & \\
\hline $\mathrm{WHO}^{21}$ & \multicolumn{2}{|l|}{-} & - & \multicolumn{2}{|c|}{$6 \times 10^{-6}\left(1 \mu \mathrm{g} \mathrm{m}^{-3}\right) \mathrm{UR} /$ lifetime } & \multicolumn{2}{|c|}{$260 \mu \mathrm{g} \mathrm{m}^{-3} 1$ week } & \multicolumn{2}{|l|}{ - } & \multicolumn{2}{|c|}{$125 \mu \mathrm{g} \mathrm{m}^{-3} 24 \mathrm{~h}$-average } \\
\hline
\end{tabular}

n.d. - below detection limit $1 \mu \mathrm{g} \mathrm{m}^{-3} ;\left(^{*}\right)$ not analyzed; (-) values for $24 \mathrm{~h}$-average not suggested; $\mathrm{n}=$ number of sampling days. 
Inhalable particles $\left(P M_{10}\right)$

Inhalable particle concentrations were measured only in the second evaluation (Apr-May/99). Table 1 shows average, minimum and maximum concentrations of inhalable particles obtained for each monitoring station during the second campaign and suggested limits. The average concentrations for all stations do not exceed the national and international daily limits $\left(150 \mu \mathrm{g} \mathrm{m}^{-3}\right)$. Conforto registered the lowest concentrations that may probably be explained by the wind regime and the location of sampling sites. This fact confirms the results found for TSP. The ratio of $\mathrm{PM}_{10} / \mathrm{TSP}$ was greater than 0.5 for all points, highlighting the relevance of the $\mathrm{PM}_{10}$ contribution to the TSP, that is, more than $50 \%$ correspond to $\mathrm{PM}_{10}$. In downtown Rio de Janeiro, average values within 57-100 $\mu \mathrm{g} \mathrm{m}^{-3} \mathrm{PM}_{10}$ were detected, i.e., similar to the average values found in Volta Redonda (44-78 $\left.\mu \mathrm{g} \mathrm{m}^{-3}\right){ }^{1}$
According to Table 2, the concentrations found in other cities $\left(24-96 \mu \mathrm{g} \mathrm{m}^{-3}\right)$ are also similar.

\section{Metals}

Table 2 shows the concentrations of airborne trace metals at each station and international standard limits besides concentrations obtained in other cities. Zinc and iron presented the highest concentrations. Zinc concentration ranged from 2.5 to $7.0 \mu \mathrm{g} \mathrm{m}^{-3}$ in TSP and 0.006 to $4.3 \mu \mathrm{g} \mathrm{m}^{-3}$ in $\mathrm{PM}_{10}$, corresponding to $3-5 \%$ and $5-10 \%$ of metal concentration, respectively. Iron concentration ranged from 2.1 to $5.2 \mu \mathrm{g} \mathrm{m}^{-3}$ in TSP and 1.4 to $3.7 \mu \mathrm{g} \mathrm{m}^{-3}$ in $\mathrm{PM}_{10}$, representing $2-5 \%$ and $3-6 \%$ of metal concentration, respectively. Chromium and vanadium concentrations were below the detection limit. Lead concentrations did not exceed the daily standard established by EEA ${ }^{19}$ $\left(3 \mu \mathrm{g} \mathrm{m}^{-3}\right)$ and $\mathrm{USEPA}^{20}\left(1.5 \mu \mathrm{g} \mathrm{m}^{-3}\right.$ quarterly average). For

Table 2. Heavy metals found in particulate matter in Volta Redonda and other cities and guideline values

\begin{tabular}{|c|c|c|c|c|c|c|c|c|c|c|c|c|c|c|c|c|c|}
\hline \multirow[t]{2}{*}{ Reference } & \multirow[t]{2}{*}{ Sites } & \multicolumn{8}{|l|}{$\mathrm{PM}_{10}$} & \multicolumn{8}{|l|}{$\mathrm{TSP}$} \\
\hline & & $\mathrm{PM}_{10}^{\#}$ & $\mathrm{Cd}$ & $\mathrm{Cu}$ & $\mathrm{Fe}^{\#}$ & $\mathrm{Mn}$ & $\mathrm{Ni}$ & $\mathrm{Pb}$ & $\mathrm{Zn}^{\#}$ & $\mathrm{TSP}^{\#}$ & $\mathrm{Cd}$ & $\mathrm{Cu}$ & $\mathrm{Fe}^{\#}$ & $\mathrm{Mn}$ & $\mathrm{Ni}$ & $\mathrm{Pb}$ & $\mathrm{Zn}^{\#}$ \\
\hline 22 & Urban - Taiwan & 62 & 8 & 24 & 0.5 & 26 & 16 & 373 & 0.2 & 113 & 8.5 & 198 & 1.2 & 84 & 16 & 573 & 0.4 \\
\hline \multirow[t]{2}{*}{23} & Urban - Greece & 87 & 1.2 & 118 & $*$ & 33 & 7 & 77 & 0.1 & $*$ & $*$ & * & $*$ & $*$ & $*$ & $*$ & $*$ \\
\hline & Industrial & 96 & 2.3 & 70 & $*$ & $*$ & 13 & 62 & 0.7 & $*$ & $*$ & $*$ & $*$ & $*$ & * & $*$ & $*$ \\
\hline \multirow[t]{2}{*}{24} & Urban - La Coruna & 48 & 0.7 & $*$ & 0.6 & 12 & $*$ & 30 & 0.07 & * & & * & & & $*$ & & $*$ \\
\hline & Industrial & 25 & 0.9 & $*$ & 0.4 & 7 & $*$ & 27 & 0.007 & 56 & 0.9 & * & 0.8 & 12 & * & 32 & 0.08 \\
\hline 25 & Urban - Argentina & $*$ & $*$ & $*$ & $*$ & $*$ & $*$ & $*$ & $*$ & 65 & 0.4 & 29 & 1.2 & 25 & 3 & 64 & 0.3 \\
\hline 26 & Urban - Washington & $*$ & $*$ & $*$ & $*$ & * & * & $*$ & $*$ & $*$ & 3.5 & $*$ & $*$ & * & $*$ & 1420 & 0.1 \\
\hline 26 & Urban - Chicago & $*$ & $*$ & $*$ & $*$ & $*$ & $*$ & $*$ & $*$ & $*$ & 6 & $*$ & * & $*$ & $*$ & 1500 & 0.6 \\
\hline 27 & Urban - Illinois & $*$ & * & $*$ & $*$ & $*$ & * & $*$ & $*$ & $*$ & $*$ & 5.4 & 0.2 & 10.1 & 1.2 & 209 & 0.03 \\
\hline 28 & Urban - Birmingham & * & $*$ & $*$ & $*$ & $*$ & $*$ & * & $*$ & $*$ & $*$ & $12-66$ & $\begin{array}{l}0.25- \\
0.35\end{array}$ & $10-23$ & $2.2-7.4$ & $69-113$ & $\begin{array}{l}0.06- \\
0.6\end{array}$ \\
\hline \multirow[t]{7}{*}{ This paper } & FEEMA & 78 & 8 & 50 & 3.0 & 200 & 20 & 130 & 0.006 & 154 & 5 & 70 & 3.2 & 200 & 20 & 90 & 6.9 \\
\hline & Belmonte & 65 & 4 & 160 & 3.7 & 200 & $\mathrm{~b}$ & 180 & 3.4 & 110 & 14 & 190 & 5.2 & 300 & 30 & 180 & 4.2 \\
\hline & Retiro & $*$ & $*$ & $*$ & $*$ & $*$ & $*$ & $*$ & $*$ & 90 & $\mathrm{~b}$ & 200 & 4.3 & 200 & 15 & 150 & 3.5 \\
\hline & Aeroclube & $*$ & $*$ & * & $*$ & $*$ & $*$ & * & $*$ & 68 & $\mathrm{~b}$ & 97 & 2.1 & 100 & 17 & 610 & 3.6 \\
\hline & Conforto & 44 & $\mathrm{~b}$ & 580 & 1.4 & 100 & b & 110 & 4.3 & 87 & $\mathrm{~b}$ & 242 & 3.2 & 200 & $\mathrm{~b}$ & 90 & 2.4 \\
\hline & Average & 62 & 4 & 263 & 2.7 & 166 & 6.6 & 140 & 2.5 & 102 & 4 & 160 & 4 & 200 & 16 & 224 & 4 \\
\hline & & \pm 17 & \pm 4 & \pm 280 & \pm 1 & \pm 58 & \pm 1 & \pm 36 & \pm 2 & $\pm \mathbf{3 3}$ & \pm 6 & \pm 73 & \pm 1 & \pm 71 & \pm 11 & \pm 219 & \pm 2 \\
\hline \multirow{4}{*}{\multicolumn{2}{|c|}{$\begin{array}{l}\text { CONAMA }^{18} \\
\text { standards }\end{array}$}} & $150 \mu \mathrm{g}$ & - & - & - & - & - & - & - & $240 \mu \mathrm{g}$ & & & & & & & \\
\hline & & $\mathrm{m}^{-3}$ & & & & & & & & $\mathrm{~m}^{-3}$ & & & & & & & \\
\hline & & $24 \mathrm{~h}$ & & & & & & & & $24 \mathrm{~h}$ & & & & & & & \\
\hline & & average & & & & & & & & average & & & & & & & \\
\hline \multirow{4}{*}{$\begin{array}{l}\text { EEA }^{19} \\
\text { standards }\end{array}$} & & - & $0.05 \mu \mathrm{g}$ & - & - & $0.15 \mu \mathrm{g}$ & $1 \mu \mathrm{g}$ & $3.0 \mu \mathrm{g}$ & - & $250 \mu \mathrm{g}$ & & & & & & & \\
\hline & & & $\mathrm{m}^{-3}$ & & & $\mathrm{~m}^{-3}$ & $\mathrm{~m}^{-3}$ & $\mathrm{~m}^{-3}$ & & $\mathrm{~m}^{-3}$ & & & & & & & \\
\hline & & & $24 \mathrm{~h}$ & & & annual & $24 \mathrm{~h}$ & $24 \mathrm{~h}$ & & $24 \mathrm{~h}$ & & & & & & & \\
\hline & & & average & & & mean & average & average & & average & & & & & & & \\
\hline \multirow{4}{*}{\multicolumn{2}{|c|}{ USEPA $^{20}$ standards }} & $150 \mu \mathrm{g}$ & - & - & - & - & - & $1.5 \mu \mathrm{g}$ & - & - & & & & & & & \\
\hline & & $\mathrm{m}^{-3}$ & & & & & & $\mathrm{~m}^{-3}$ & & & & & & & & & \\
\hline & & $24 \mathrm{~h}$ & & & & & & & & & & & & & & & \\
\hline & & average & & & & & & & & & & & & & & & \\
\hline \multirow{4}{*}{\multicolumn{2}{|c|}{$\mathrm{WHO}^{21}$ standards }} & - & - & - & - & $0.15 \mu \mathrm{g}$ & - & - & \\
\hline & & & & & & & & & \multicolumn{9}{|c|}{$\mathrm{m}^{-3}$} \\
\hline & & & & & & annual & & & \multirow{2}{*}{\multicolumn{9}{|c|}{$\begin{array}{l}24 \mathrm{~h} \\
\text { average }\end{array}$}} \\
\hline & & & & & & mean & & & & & & & & & & & \\
\hline
\end{tabular}

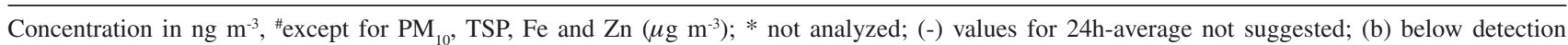
limit. 
manganese, if it was considered the annual $\mathrm{WHO}^{21}$ standard for Europe $\left(0.15 \mu \mathrm{g} \mathrm{m}^{-3}\right)$ it was exceeded in all stations, except Aeroclube. $\mathrm{Cd}$ and $\mathrm{Ni}$ did not exceed the limit suggested by EEA ${ }^{19}$ in TSP and $\mathrm{PM}_{10}, 0.05 \mu \mathrm{g} \mathrm{m}^{-3}$ and $1 \mu \mathrm{g} \mathrm{m}^{-3} 24 \mathrm{~h}$-average, respectively. $\mathrm{Zn}$ also did not surpass daily standard established by $\mathrm{WHO}^{21}\left(100 \mu \mathrm{g} \mathrm{m}^{-3}\right)$ in both kinds of particles. $\mathrm{Cu}$ and $\mathrm{Fe}$ do not have standards established by these agencies.

Half of airborne trace metals in Volta Redonda area are higher than average values reported for urban particulates. In $\mathrm{PM}_{10} \mathrm{Cu}, \mathrm{Fe}, \mathrm{Mn}$ and $\mathrm{Zn}$ and in TSP Fe, Mn and $\mathrm{Zn}$ presented average concentrations higher than other cities (Table 2). When compared to Brazilian levels, Fe concentrations found in Volta Redonda $\left(2-5 \mu \mathrm{g} \mathrm{m}^{-3}\right.$ in TSP and 1.5-4.0 $\mu \mathrm{g} \mathrm{m}^{-3}$ in $\mathrm{PM}_{10}$ ) were similar to Rio de Janeiro ${ }^{1}$ (1.5-3.0 $\mu \mathrm{g} \mathrm{m}^{-3}$ in TSP and 1.5-2.0 $\mu \mathrm{g} \mathrm{m}^{-3}$ in $\left.\mathrm{PM}_{10}\right)$. In the same way, zinc concentrations were $4.5-6.0 \mu \mathrm{g} \mathrm{m}^{-3}$ in TSP in Rio de Janeiro ${ }^{1}$ and 2.0-7.0 $\mu \mathrm{g} \mathrm{m}^{-3}$ in TSP in Volta Redonda. For most of toxic trace metals $(\mathrm{Pb}, \mathrm{Cd}, \mathrm{Zn}, \mathrm{Ni}$, $\mathrm{Cu})$ anthropogenic inputs are more important than natural sources. ${ }^{25}$ In Volta Redonda, anthropogenic sources seem to be responsible for the high metal concentrations, mostly industry related sources such as CSN (Al, Mn, Cr, Sn, Zn and mainly Fe), FEM (mainly Fe), CESBRA (Sb, Bi, Ni, $\mathrm{Ag}, \mathrm{Zn}, \mathrm{Pb}$ and mainly $\mathrm{Sn}$ ) and Voldac (Mn, $\mathrm{Cu}$ and mainly $\mathrm{Fe}$ ). The wind direction from Northeast to Southwest proves these results since that the highest metal concentrations were registered in Belmonte and FEEMA stations. It is believed that CESBRA and Voldac have minor influence in metal concentration in the stations due to distance, but they are also emitting.

These results are of some concern as it is well established that inhalable particles that have higher concentrations of many trace elements such $\mathrm{Pb}, \mathrm{Cd}, \mathrm{Zn}$, $\mathrm{Cr}, \mathrm{Ni}, \mathrm{Mn}$ and $\mathrm{Cu}$ are correlated with pulmonary toxicity. ${ }^{23,25}$

\section{Benzene, toluene and xylenes (BTX)}

Table 1 presents the results of BTX levels obtained in the Municipal District of Volta Redonda in both evaluations. In the first evaluation (Dec/95-May/96) average concentrations for benzene, toluene, xylenes were $70 \mu \mathrm{g} \mathrm{m}^{-3}, 23 \mu \mathrm{g} \mathrm{m}^{-3}$ and $2.5 \mu \mathrm{g} \mathrm{m}^{-3}$, respectively. In the second one (Apr-May/99), the arithmetic means were for benzene $23 \mu \mathrm{g} \mathrm{m}^{-3}$, toluene $4 \mu \mathrm{g} \mathrm{m}^{-3}$ and xylenes $0.6 \mu \mathrm{g} \mathrm{m}^{-3}$. Benzene concentrations in the second evaluation (Apr-May/99) presented values approximately four times lower than in the first one (1995-96). Toluene levels presented a reduction from five to seven times in this last sampling (1999). Xylenes were found in low levels in both evaluations. BTX in Volta Redonda and different cities are presented in Table 3. Reported average concentrations of benzene has been for South America cities 5-24 $\mu \mathrm{g} \mathrm{m}^{-3}$, Europe, North America and Oceania, $<5 \mu \mathrm{g} \mathrm{m}^{-3}$ and Asia, 7-31 $\mu \mathrm{g} \mathrm{m}^{-3}$ (except Calcuta 28,555 $\mu \mathrm{g} \mathrm{m}^{-3}$ ). ${ }^{10,29}$ Benzene levels in Volta Redonda, in the first evaluation (Dec/95-May/96), were among the highest in cities. In the

Table 3. BTX average concentrations in Volta Redonda and other regions of the world

\begin{tabular}{|c|c|c|c|c|c|}
\hline Site & Benzene $\left(\mu \mathrm{g} \mathrm{m}^{-3}\right)$ & Toluene $\left(\mu \mathrm{g} \mathrm{m}^{-3}\right)$ & Xylenes $\left(\mu \mathrm{g} \mathrm{m}^{-3}\right)$ & Source & Reference \\
\hline South America & & & & & $1,10,12,29$ \\
\hline Brazil (RJ) & nd-11 & - & - & Traffic & \\
\hline Brazil (SP) & $5-30$ & $11-75$ & $2-38$ & Traffic & \\
\hline Brazil (POA) & 25 & 43 & $11-28$ & Traffic & \\
\hline Chile & $7-40$ & $9-55$ & $3-59$ & Traffic & \\
\hline Venezuela & $3-44$ & $15-56$ & $3-27$ & Traffic & \\
\hline North America & & & & & $1,21,29$ \\
\hline USA & $1-16$ & - & - & Industry & \\
\hline USA & 6 & - & - & Traffic & \\
\hline USA & 1.5 & - & - & Rural area & \\
\hline Europe & & & & & $1,29-32$ \\
\hline Germany & $10-30$ & - & - & Cokery & \\
\hline Germany & $1-15$ & - & - & Industry & \\
\hline Germany & $1-3$ & - & - & Traffic & \\
\hline Denmark & $3-5$ & - & - & Traffic & \\
\hline Asia & & & & & $10,29,33,34$ \\
\hline India & $576-918$ & $183-258$ & $6-124$ & Industry & \\
\hline India & $11-28,555$ & $30-4,036$ & $24-796$ & Industry & \\
\hline Thailand & $3.4-35$ & $29-559$ & $3-249$ & Traffic & \\
\hline Philipines & nd-47 & $9-807$ & nd -170 & Traffic & \\
\hline Volta Redonda & & & & & This work \\
\hline $1995-96$ & $70 \pm 17$ & $23 \pm 5$ & $2.5 \pm 0.6$ & Industry & \\
\hline 1999 & $23 \pm 4$ & $4 \pm 0.5$ & $0.6 \pm 0.6$ & Industry & \\
\hline
\end{tabular}

nd, not detected; -, not determined. 
second campaign these indices decreased and remained within the levels found in the cities of Latin America and Brazil. The other compounds occurred in low levels similar to other Brazilian cities.

BTX do not have recommended limits according to Brazilian legislation. But following $\mathrm{WHO}^{21}$ and EEA ${ }^{19}$ standards, average values for toluene and xylenes did not exceed the limit suggested in both campaigns (Table 1). Benzene is a special case for presenting health risk even in low concentrations. Therefore it does not have a standard value but a reference concentration. $\mathrm{WHO}^{21}$ considered that the excess lifetime risk of leukemia at an air concentration of $1 \mu \mathrm{g} \mathrm{m}^{-3}$ is $6 \times 10^{-6}, i$. e., six extra-cases of leukemia in a million people exposed during their life. FEEMA adopts as reference the limits suggested by the Germany Governmental $\operatorname{Agency}^{35}\left(2.5 \mu \mathrm{g} \mathrm{m}^{-3}\right)$ and $\mathrm{WHO}^{21}\left(1.0 \mu \mathrm{g} \mathrm{m}^{-3}\right)$. In both cases, all values found for benzene in Volta Redonda exceeded the reference concentration in both evaluations.

In Volta Redonda benzene concentrations ranged from 52 to $93 \mu \mathrm{g} \mathrm{m}^{-3}$ in the first evaluation (Dec/95-May/96), and from 20 to $26 \mu \mathrm{g} \mathrm{m}^{-3}$ in the second one (Apr-May/99). Maximum concentration was $1644 \mu \mathrm{g} \mathrm{m}^{-3}$ at Retiro (1995/ 96) and $104 \mu \mathrm{g} \mathrm{m}^{-3}$ at FEEMA (1999). These average concentrations could correspond to 120 up to 558 extra-cases of leukemia in a population of a million exposed citizens. Considering Volta Redonda population around 250,000 inhabitants this would mean 78 to 140 extra-cases and 30 to 40 extra-cases in the first and second evaluations, respectively. These estimates of extra-cases of leukemia may be real since the Secretary of Health from Volta Redonda ${ }^{36}$ registered 688 cases of benzenism from 1984 to 1999 . The actual number is probably higher because several symptomatic cases are not recognized by the Brazilian Health Integrated System yet. Also, in Cubatão, other big steel producer, hundreds of workers were diagnosed with benzenism, due to exposure in coke producing ovens. ${ }^{37}$ Benzenism was also prevalent in other activities, mainly in the petrochemical and oil industries but no estimate of the population potentially exposed in Brazil has been advanced. ${ }^{37}$

To evaluate the source of BT pollution it is possible to consider the $\mathrm{T} / \mathrm{B}$ ratio. Depending on gasoline composition T/B from 2 to 3 indicates traffic as a main source of pollution, while values less than 0.5 correspond predominantly to industrial sources. ${ }^{10}$ Average ratio in the first evaluation (Dec/95-May/96) was: 0.4 (FEEMA), 1.1 (Belmonte), 0.3 (Retiro), 0.4 (Aeroclube) and 0.3 (Centro de Pesquisass). In the second evaluation (April-May/99) FEEMA presented a ratio T/B of 0.22 and Retiro one of 0.14 . These ratios suggest that, during both evaluations, the organic compound pollution is basically due to industrial emissions. According to meteorological information, the predominant wind direction in the region is East to West, varying from Northeast to Southeast. In both evaluations, the maximum concentration of benzene was obtained at the North and Southeast sections of the studied area, in other words, in Retiro and FEEMA. Wind direction correlation with aromatic hydrocarbon levels permitted to establish the location of the source: the coke producing facility of CSN.

\section{Sulphur dioxide}

Sulphur dioxide concentrations were measured only at FEEMA, with an automatic equipment that registered hourly its average concentration. $\mathrm{SO}_{2}$ average concentrations were $186 \mu \mathrm{g} \mathrm{m}^{-3}$ on the first evaluation (Dec/95-May/96) and $73 \mu \mathrm{g} \mathrm{m}^{-3}$ on the second one (AprMay/99) (Table 1). There was a significant decrease of $\mathrm{SO}_{2}$ concentration between the two evaluations, 2.5 times. Both average concentrations did not exceed the established standards by CONAMA ${ }^{18}$ and USEPA $^{20}\left(365 \mu \mathrm{g} \mathrm{m}^{-3}-24 \mathrm{~h}\right)$ and $\operatorname{EEA}^{19}\left(300 \mu \mathrm{g} \mathrm{m}^{-3}\right)$. But in the first evaluation (Dec/ 95-May/96) $\mathrm{WHO}^{21}$ daily standards ( $\left.125 \mu \mathrm{g} \mathrm{m}^{-3}-24 \mathrm{~h}\right)$ were exceeded on about $30 \%$ of the samplings. According to WHO, ${ }^{21} \mathrm{SO}_{2}$ is also toxic for vegetation in annual concentrations from 10 to $30 \mu \mathrm{g} \mathrm{m}^{-3}$, i. e., the concentrations found in Volta Redonda can originate acid rain, which can damage trees, lakes, and soil.

The results obtained in Volta Redonda (73-186 $\mu \mathrm{g} \mathrm{m}^{-3}$ ) are lower than those obtained in the metropolitan area of Rio de Janeiro (140-300 $\left.\mu \mathrm{g} \mathrm{m}^{-3}\right){ }^{1}$

The highest concentration peaks occurred when the wind blew from Northeast to East. Lower concentrations were obtained with the wind blowing from West to Northwest. These results indicate that burning of coal in $\mathrm{CSN}$ is the major source of $\mathrm{SO}_{2}$ in that city. It was confirmed by fact that the daily concentrations of $\mathrm{SO}_{2}$ and benzene present similar behavior (Figure 2), that is, the main emission sources for both compounds is the same.

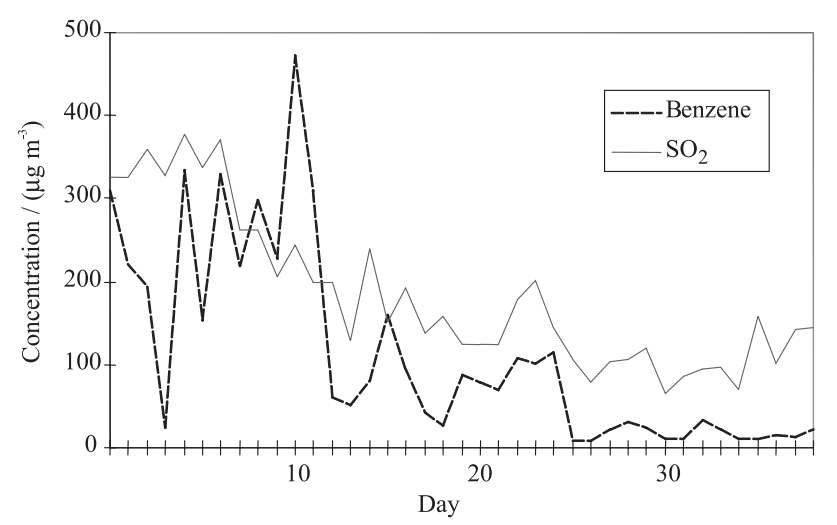

Figure 2. Correlation between $\mathrm{SO}_{2}$ and benzene concentrations at FEEMA station in first evaluation (Dec/95-May/96). 


\section{Conclusions}

TSP in Volta Redonda presented average levels that did not exceed $24 \mathrm{~h}$-standards by CONAMA ${ }^{18}\left(240 \mu \mathrm{g} \mathrm{m}^{-3}\right)$ and $\operatorname{EEA}^{19}\left(250 \mu \mathrm{g} \mathrm{m}^{-3}\right)$. Also, the concentrations found were lower than for other Brazilian and foreign cities, not being the major pollutant in that city. In accordance with wind direction and locations of monitoring sampling sites the most probable source of TSP in Volta Redonda is the CSN plant (handling of ores and burning of coal) followed by Tupy cement (crushing and blending of limestone and grinding to a fine powder).

$\mathrm{PM}_{10}$ levels were below daily limits established by CONAMA $^{18}$ and $\operatorname{USEPA}^{20}\left(150 \mu \mathrm{g} \mathrm{m}^{-3}\right)$. $\mathrm{PM}_{10}$ corresponds to more than $50 \%$ of TSP, indicating anthropogenic sources for particulate matter. The concentrations found were similar to other cities.

All metals monitored were in high concentration, except $\mathrm{V}, \mathrm{Cr}$ (not detected) and $\mathrm{Cd}$. The highest concentrations were detected for $\mathrm{Zn}$ and Fe. These metals together with $\mathrm{Mn}$, are among the most used by the local industries. Only Mn exceeded the limit suggested by $\mathrm{WHO}^{21}$ and $\operatorname{EEA}^{19}\left(0.15 \mu \mathrm{g} \mathrm{m}^{-3}\right)$ if it were considered as annual average, except in Aeroclube. Metal concentrations occurred mainly in TSP $(\mathrm{Fe}, \mathrm{Cu}, \mathrm{Mn}$ and $\mathrm{Zn}$ ). The high concentration of metals can be attributed to several industries in Volta Redonda (CSN, FEM, Voldac and CESBRA). FEEMA and Belmonte stations were more affected stations by metal concentrations due to proximity to emission sources. Elevated concentration of metals in PM found in Volta Redonda can jeopardize population health, for example pulmonary diseases, mainly in susceptible people. These results are punctual and do not allow many conclusions about exact emission sources, metal distribution in particulate matter and annual average concentrations. Further research is definitely needed.

BTX, mainly BT, presented high concentrations (70 $\mu \mathrm{g} \mathrm{m}^{-3}, 23 \mu \mathrm{g} \mathrm{m}^{-3}, 2.5 \mu \mathrm{g} \mathrm{m}^{-3}$, respectively ) in the first evaluation (Dec/95-May/96) being reduced 4 to 7 times in the second one $\left(23 \mu \mathrm{g} \mathrm{m}^{-3}, 4 \mu \mathrm{g} \mathrm{m}^{-3}, 0.6 \mu \mathrm{g} \mathrm{m}^{-3}\right.$, respectively), but benzene values were still high. Toluene and xylenes did not go above the limits suggested by $\mathrm{WHO}^{21}$ and EEA ${ }^{19}$. Benzene is toxic in any concentration, therefore it can be considered to be the major airborne pollutants in Volta Redonda. T/B ratios were lower than 0.5 reinforcing industrial emissions as the pollution source. Consistent with meteorological information, the highest levels of BTX were obtained leeward to CSN coke producing plant, pinpointing it as their major emission source. Elevated benzene concentrations can be influencing directly on population health in Volta Redonda confirmed by lofty benzenism index (688 registered cases from 1984 to 1999).

$\mathrm{SO}_{2}$ concentrations were below the $24 \mathrm{~h}$-average according to CONAMA ${ }^{18}$ and $\operatorname{USEPA}^{20}\left(365 \mu \mathrm{g} \mathrm{m}^{-3}\right)$ but exceeded $\mathrm{WHO}^{21}$ limits in the first evaluation (Dec/95May/96) $\left(125 \mu \mathrm{g} \mathrm{m}^{-3}\right)$. In the second the levels were reduced by 2.5 times. But, these indices are still high for vegetation. According to meteorological data the highest concentrations were obtained when the wind blew from CSN to FEEMA station indicating the burning of coal as main emission source.

In conclusion, monitored air composition showed that the industrial activity is the predominant pollution source in Volta Redonda, possibly due to gaseous emissions during coke production and raw benzene storage. It was evident that, in general, the highest registered values of concentration for each monitoring air quality station occurs leeward from CSN, and that the lower values occurs windward. The analysis of the results in the second monitoring evaluation of air quality, especially with regards to the organic compounds and sulphur dioxide, showed that the concentration levels of these pollutants were significantly reduced in relation to the values on the first one. This fact confirms that the pollution control measures adopted by CSN, after the first evaluation (Dec/95-May/ 96), such as benzene storage leakage control system, flotation membranes and the change of the coke oven's doors control system, resulted in a great reduction of the pollution levels at the surveyed area.

The small budget available to governmental entities such as FEEMA for monitoring campaigns together with their high cost has limited the sampling period. However, this work, in spite of limited data, had great importance to improve air quality in Volta Redonda. Based on this research, drastic measures were enforced decreasing the levels of pollutants by more than $70 \%$ which will benefit hundreds of citizens and the environment.

\section{Acknowledgements}

FAPERJ, CNPq, CAPES and FUJB for research grants.

\section{References}

1. FEEMA, Rio de Janeiro State Environmental Engineering Foundation; Air Quality in Volta Redonda, Report of Results Obtained in Monitoring Evaluation of 96 and 99, FEEMA/ GTZ, 1999 (document in Portuguese).

2. Fang, G. C.; Chang, C. N.; Wu, Y. S.; Fu, P. P. C.; Yang, D. G.; Chu, C. C.; Sci. Total Environ. 1999, 234, 203. 
3. Martinis, B. S.; Kado, N. Y.; Carvalho, L. R. F.; Okamoto, R. A.; Gundel, L. A.; Mut. Res. 1999, 446, 83.

4. Bono, R.; Bugliosi, E. H.; Schiliro, T.; Gilli, G.; Atmos. Environ. 2001, 35, S107.

5. Grosjean, D.; Miguel, A. H.; Tavares, T. M.; Atmos. Environ. 1990, 24B, 101.

6. Allen, A. G.; Miguel, A. H.; Atmos. Environ. 1995, $29,3519$.

7. Daisey, J. M.; Miguel, A. H.; de Andrade, J. B.; Pereira; P. A. P.; Tanner, R. L.; J. Air Pollut. Control Assoc. 1987, 37, 15.

8. Tanner, R. L.; Miguel, A. H.; Aerosol Sci. Technol. 1989, 10, 213.

9. Azevedo, D. A.; Moreira, L. S.; Siqueira, D. S.; Atmos. Environ. 1999, 33, 4987.

10. Fernandes, M. B.; Brickus, L. S. R.; Moreira, J. C.; Cardoso, J. N.; Chemosphere 2002, 47, 417.

11. Santos, C. Y. M.; Azevedo, D. A.; Aquino Neto, F. R.; Atmos. Environ. 2002, 36, 3009.

12. Grosjean E.; Grosjean, D.; Rasmussen, R. A.; Environ. Sci. Technol. 1998, 32, 2061.

13. Grosjean, E.; Reinhold, A. R.; Grosjean, D.; Atmos. Environ. 1998, 32, 3371.

14. de Andrade, J. B.; Andrade, M. V.; Pinheiro, H. L. C.; J. Braz. Chem. Soc. 1998, 9, 219.

15. Abas, M. R. B.; Simoneit, B. R. I.; Elias, V.; Cabral, J. A.; Cardoso, J. N.; Chemosphere 1995, 30, 995.

16. FEEMA, Rio de Janeiro State Environmental Engineering Foundation; Environmental Profile of Volta Redonda Municipality, 1991(document in Portuguese).

17. FEEMA, Rio de Janeiro State Environmental Engineering Foundation, MF-613.R-2; Method to Determine Metals in Total Particulate Matter in Air by Atomic Absorption Spectrometry, 1999 (document in Portuguese).

18. CONAMA, National Environmental Council, Resolution $n^{\circ}$ 03, 28/06/1990; Guidelines for Air Quality, Preview in PRONAR, Published in D.O.U, 22/08/90, Section I, pg. 15.937 to 15.939. Available in: http://www.lei.adv.br/003-90.htm, accessed in August 2003 (document in Portuguese).

19. EEA, European Environmental Agency; Guidelines, 2000. Available in: http://www.eea.eu.int, accessed in August 2003.

20. USEPA, US Environmental Protection Agency; National Ambient Air Quality Standards, Office of Air Quality Planning and Standards, USA, 1990. Available in: http://www.usepa.gov/ airs/criteria, accessed in August 2003.
21. WHO, World Health Organization; Air Quality Guidelines, 2nd Edition, Regional Office for Europe, 2000. Available in: http://www.euro.who.int/air/Activities, accessed in August 2003.

22. Fang, C. G.; Chang, C. N.; Chu, C. C; Wu, Y. W.; Fu, P. P. C.; Yang I. L.; Chen, M. H.; Sci. Total Environ. 2003, 308, 157.

23. Voutsa, D.; Samara, C.; Atmos. Environ. 2002, 36, 3583.

24. Beceiro-González, E. B.; Garda, J. M.; Velasco, E. S.; LópezMahía, P.; Sci. Total Environ. 1997, 196, 131.

25. Bilos, C.; Colombo, J. C.; Skorupka, C. N.; Rodrigues Preza, M. J.; Environ. Pollut. 2001, 111, 149.

26. Greenberg, R.R. In Analysis of Atmospheric Particulate Samples via Instrumental Neutron Activation Analysis - Monitoring Methods for Toxics in the Atmosphere; Zielinski Jr., W.L.; Dorko, W.D., eds. , ASTM STP 1052, American Society for Testing and Materials: Philadelphia, 1990, pp. 175-184.

27. Sweet, C. W.; Vermette, S. J.; Landsberg, S.; Environ. Sci. Technol. 1993, 27, 2502.

28. Harrison, R. M.; Smith, D. J. T.; Luhana, L.; Environ. Sci. Technol. 1996, 30, 175.

29. Gee, I. L.; Sollars, C. J.; Chemosphere 1998, 36, 2497.

30. Skov, H.; Hansen, A. B.; Lorenzen, G.; Andersen, H. V; Lofstrom, P.; Christensen, C.; Atmos. Environ. 2001, 35, 2463.

31. Schneider, P.; Gebefugi, I.; Richter, K.; Wolke, G.; Schnelle, J.; Wichmann, H. E.; Heinrich, J.; Sci. Total Environ. 2001, 267, 41.

32. Gladtke, D.; Toxicol. Lett. 1998, 96-97, 277.

33. Chattopadhyay, G.; Chatterjee, S.; Chakraborti, D.; Environ. Technol. 1996, 17, 477.

34. Samanta, G.; Chattopadhyay, G.; Mandal, B. K.; Chowdhury, T. R.; Chanda, C. R.; Banerjee, P.; Lodh, D.; Das, D.; Chakraborti, D.; Curr. Sci. 1998, 75, 123.

35. EC, European Communities, Council directive 96/62/EC of 27 September 1996; Ambient Air Quality Assessment and Management, Official Journal of the European Communities, L 296/55, 21 November 1996.

36. SSVR-RJ, Health Secretary of Volta Redonda; Report about Benzenism Cases in Volta Redonda Municipality, Health Integrated System, 1999 (document in Portuguese).

37. Freitas C. M.; Porto, M. F. S.; Freitas, N. B. B.; Pivetta, F.; Arcuri, A. S.; Moreira, J. C.; Machado, J. M. H.; J. Hazard. Mater. 2001, 86, 135. 